\title{
THE IMPLEMENTATION OF CORPORATE PARTNERSHIP PROGRAM WITH SMALL AND MEDIUM ENTERPRISES TO ENHANCE A BUSINESS GROWTH: A STUDY ON THE PARTNERSHIP OF PT. CHAROEN POKPHAND INDONESIA THROUGH PT. SINAR SARANA SENTOSA WITH BROILER CHICKEN BREEDERS IN BLITAR REGENCY
}

\author{
Haryanto Dedy Teguh*, Utami Hamidah Nayati, Prasetya Arik \\ Faculty of Administrative Science, University of Brawijaya, Indonesia \\ *E-mail: deddyteguh45@gmail.com
}

\begin{abstract}
The development of business world today has undergone much progress. Various types of businesses have started to pop up. Speaking of livestock, the livestock sector is an integral part of agricultural sector development prioritized to meet the needs of food and nutrition. The development of livestock sector is part of the overall development which aims to provide food in the form of meat, milk, and eggs which have high nutritional value as well as increasing the farmer's or breeder's income and expand the employment opportunity. The chickenbroiler is a very effective chicken to produce meat. In general, the main weaknesses in this business lie in the relatively small capital, lack of knowledge on maintaining the management capability, and relatively high price of feed. Another problem that occurs in this business is the field of marketing. One of the best ways that can be recommended in the development of broiler chicken agribusiness is the implementation of vertical coordination system with the partnership pattern. The problem discussed by the author in this study is about the partnership concept application between PT. Charoen Pokphand Indonesia through its subsidiary of PT. Sinar Sarana Sentosa and Small and Medium Enterprises (SMEs) of broiler chicken breeders in improving the business growth in Blitar. This study is conditional and can be developed after the researcher conducted the research directly. This aims to analyze the problems about the application of partnerships and factors that support and inhibit the partnership, thus, it is possible that the theory of broiler chicken breeders partnership is developed. This research uses descriptive qualitative approach. In the research results, companies and breeders also need each other. It means that the company needs good breeding results. Breeders as the plasma need guidance to maximize the results. The majority of plasma breeders that participate in the partnership program with PT. Sinar Sarana Sentosa is small-scale breeders. They choose to participate in this partnership program because they have limited capital, marketing, and technological constraints.
\end{abstract}

\section{KEY WORDS}

Broiler, chicken, SMEs, partnership.

The development of the business world today has undergone much progress. Various types of businesses began to emerge ranging from small to medium scale enterprises. Livestock business is also included in one of the business group which currently experiencing a high increase. The awareness of importance on high nutritional food needs one indicator to realize the prosperity of the community that can be met from animal protein such as meat, egg, and milk. Therefore, in the framework of livestock products procurement to meet the needs of the community, it is necessary to develop the field of livestock that produce faster products. One of the livestock commodities that has a potential to achieve this goal is broiler chicken. This encourages the development of livestock sector so that in the future it is expected to give arealcontribution to the development of national economy (Salam, et al, 2006). To achieve the development of agriculture in general and livestock in particular, a maximum productivity is needed as it acts as a support for the need of animal protein that is part of the basic human needs. In general, the maintenance only needs 35 days. In that period of time, the chicken already has an average body weight of 
$1,8 \mathrm{~kg} /$ chicken and can be sold immediately. Thus, the capital rotation could run within a short time (Muslimin, 2002). These developments are supported by stronger downstream industries such as breeding farms, feed mills, veterinary companies, and livestock equipment (Saragih, 2000).

In general, the main weaknesses in the business of broiler chicken breeders, mostly in the form of livestock farming, lie in the field of relatively small capital, lack of knowledge about the ability of maintenance management, and relatively high price of feed. Whereas, the requirement of broiler chicken itself is big enough ranging from $60-70 \%$ from production cost (Rasyaf, 2004). One of the best ways that can be advocated in the development of broiler agribusiness is to apply vertical coordination system with partnership pattern (Suparta, 2001). Livestock development is part of agribusiness which includes business on livestock production management, livestock cultivation management, processing or handling during livestock maintenance, post-harvest handling, and marketing (Tobing, 2005). This broiler chicken breeding business can involve multinational communities and small farmers community because the business capital and all other aspects are depended on the breeder itself. The livestock business can also be taken independently or in partnership (Rita, 2009).Broiler chicken breeders, mostly in the form of community livestock, are in cooperation with large companies within a partnership form (Hertanto, 2009). The partnership is expected to be a solution to spur the growth of breeders in Indonesia especially for smallholders who have relatively small capital ownership (Rasyaf, 1995). The following table shows the content of several types of livestock.

Table 1 - Nutritional Content of Chicken, Cow, and Goat

\begin{tabular}{|c|c|c|c|}
\hline Type of Meat & Protein (\%) & Water (\%) & Fat (\%) \\
\hline Broiler Chicken & 23,40 & 73,70 & 1,90 \\
\hline Cow & 21,50 & 69,50 & 7,00 \\
\hline Goat & 19,50 & 71,50 & 7,50 \\
\hline
\end{tabular}

Source: Center for Agricultural Products Industry (2009).

Based on Table 1, it is known that the levels of nutrients such as protein and water owned by broiler chicken are higher than the cows and goats while it also holds the smallest fat content. This shows that chicken meat is good to be consumed and better than other types of meat. Based on the description that has been described, it is known that broiler chicken has a very good potential to be developed. Independent breeders, generally, have small-scale businesses with limited capital and technology. This condition causes independent breeders to become more vulnerable to the impact of economic crisis.

In a partnership business, the price of livestock production facilities and the price of chicken are determined by the partnered company in a partnership contract agreed upon by both parties. The partnership is also expected to be one of the solutions to stimulate the growth of livestock agribusiness, especially to overcome the problems of small-scale breeders (Abidin, 2002). The maintenance management includes all activities of broiler chicken production in the cage. This consists of aselection ofday old chicks, feeds, vaccine administration, labor organization, and other matters concerning broiler chicken breeding management (Rasyaf 2004). Limited technology owned by breeders is also a problem that can generate less efficient production. Apart from the above developments, a partnership of broiler chicken breeders is a strategy to increase the livestock sector in meeting the market needs and to help the breeders who belong to Small and Medium Enterprises (SMEs) in improving the development of livestock sector for the better.

SMEs are a means of independence for many small entrepreneurs. No matter how small it is, the independent entrepreneurs are not dependent on others but the quality of human resources as a business actor. According to Siahaan, Rambe and Mahidin (2006: 11), empowerment can be interpreted as an attempt to increase the ability of a person or a group to carry out the duties and authority as the performance of the task. The problems concerning SMEs in the livestock sector, especially broiler chicken breeders have made PT. Charoen Pokphand Indonesia to help SMEs increasing the growth of broiler chicken 
breeding in Blitar with a partnership strategy. In correlation with the partnership, PT. Charoen Pokphand Indonesia already has its own subsidiary which was established to focus in the partnership of broiler chicken namely PT. Sinar Sarana Sentosa (PT. SSS). This incorporated company was established on January 1, 2000, with its original name, NUJ (Nusantara Unggas Jaya) before it changed to PT. SSS in 2008.

Table 2 - Poultry population by type in Blitar

\begin{tabular}{|c|c|c|c|}
\hline Year & Ayam Kampung & Ayam Petelur & Broiler Chicken \\
\hline 2015 & 2596300 & 14973000 & 965600 \\
\hline 2014 & 2583400 & 14679500 & 955600 \\
\hline 2013 & 2857800 & 15336300 & 1194500 \\
\hline 2012 & 2555780 & 15336300 & 4992100 \\
\hline 2011 & 2341098 & 13900400 & 21873600 \\
\hline
\end{tabular}

Source: Central Bureau of Statistics, Blitar.

The data in Table 2 shows that every year, most of the livestock population in Blitar has decreased because of the lack of management knowledge ranging from breeding to selling process. Another obstacle is the market condition that there started to be many broiler chicken breeders. This indicates that the livestock in Blitar needs more special attention from the livestock service up to the broiler chicken breeders to continue to be developed as an effort to fulfill the needs of the meat whether in thelocal market or in provincial level. The broiler chicken industry has such competitiveness or comparative advantage in its business. Broiler chicken breeding is intended to fulfill domestic needs that are economically efficient in the utilization of domestic resources (Siregar and Rusastra, 2002). This potential can be seen from the development of broiler chicken population in Blitar.

\section{LITERATURE REVIEW}

Implementation Concept. Browne and Wildavsky (Usman, 2004) suggested that "implementation is an extension of mutually adjusting activities". According to Syaukani et al (2004), implementation is a series of activities to deliver the policy to the community so that the policy can bring the results as expected. The series of these activities include the preparation of follow-up rules that become the interpretations of the policy. Second, the preparation of resources to mobilize the implementation including all facilities and infrastructure, financial resources, and the determination of who is responsible for the implementation of the policy. Lastly, is about how to convey the policy concretely to the community.

Program Implementation Model. One of the models of this program implementation is the model disclosed by David C. Korten. This model uses the learning process approach and better known as the suitability model of program implementation. Korten's suitability model is described as follows:

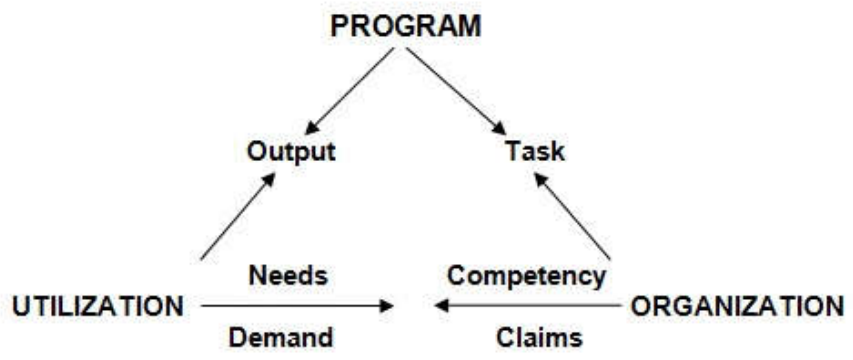

Figure 1 - The Concept of Program Utilization

Korten described this model into three elements that exist in the program implementation such as the program itself, program implementation, and program target. $A$ 
program is said to be successfully implemented if there is a conformity in between those three elements of program implementation. First, the suitability of the program with the beneficiaries such as the suitability of what is offered by the program and what is needed by the target group (beneficiaries). Secondly, the suitability of the program and the implementing organization such as the suitability of the tasks required by the program and the capability of the implementing organization. Third, the agreement between groups of users with the implementing organization, the demands of the organization, the decision management program, and the output of task competency that is the suitability in between the requirements of the organization to obtain the output of the program and things that can be done by the target group (Akib and Tarigan, 2000).

The Concept of Local Economic Development (LED). The Concept of Development from Bottom allows the smaller territory to construct themselves independently as it is separated from the rest of the world. However, in fact, a development is more directed to a market system. As a result, the relationship in between territories has no limit which then is known as globalization. This means that the Concept of Development from Bottom is very difficult to implement. This concept has been developed in the context of Western Europe but has increasingly perceived its relevance to developing countries such as Indonesia (Firman 2007). Blakely (1989) adds that local economic development is a process whereby local governments and/or community groups manage the existing resources and take part in the partnership with the private sector or others as well as create jobs and stimulate economic activities within the economic zones. In line with the above statement, Schumpeter (1961) in Coffey and Polese (1984) added that the concept of LED is built on the entrepreneurial spirit which can be a major driver for the economy of society. Furthermore, Coffey and Polese (1984) in Todoro 2000 provide an understanding of LED as an enhancement of the role of endogenous elements in the socio-economic life of a locality while keep maintaining its functional and spatial linkages and integration with the wider region.

Understanding of Broiler Chicken. Broiler chicken is one type of poultry that grows rapidly, after experiencing a breeding as a superior broiler Abidin (2002). The advantage of broiler breeding business is the type of livestock that has a relatively fast growth rate so that the selling age is quite short, 4-5 weeks. Meanwhile, the disadvantage of this broiler chicken is the fact that it often competes with humans in the stock of food and its resistance against disease is low when compared to Ayam kampung (Rasyaf, 2004). Broiler chicken is a term that refers to the strains of technological chicken-results that have economic characteristics. This has a characteristic of rapid growth rate as a meat producer with an economical conversion (Abidin, 2002).

Partnership. The partnership comes from the word "partner" which means friend or colleague. Partnership arises because there are at least two partners. The desire to have a partner comes from each side, although it can also happen that partnership arises from the role of third parties (Salam, et al, 2006). In regard to the first thing, broiler chicken breeding is one of the sub-systems of broiler farm agribusiness. Today, we no longer develop livestock merely in terms of cultivation or no longer approach how breeders produce broiler chicken but we must approach the agribusiness comprehensively. As for examples, the approach in the sub-systems of input procurement or pre-production sub-systems, the approach in subsystems of cultivation or production processes and in sub-systems of processing and marketing or post-production sub-systems, and the approach of components or other factors associated with the agribusiness system (Saragih, 2000). According to Rita (2009), the partnership is cooperation in between various parties both vertically on small businesses with a medium or large businesses and horizontally on the same scale enterprises. This must be conducted in regard to the principle of mutual need or mutual reinforcement. In line with this concept, Saptana et al. (2006) said that a business partnership supports economic efficiency because each partyoffers its advantages in an attempt to strengthen the market mechanisms, cost of capital, and/or to promote its products.

The pattern of partnership that takes place between companies and broiler chicken breeders is the core pattern of the plasma; the company acts as the core and the breeders as the plasma. The core provides day-old chicks (DOC), vaccines and feeds during the 
maintenance activities while the plasma breeders provide land and cages. Supervision and guidance are technically done by the core company while ensuring the marketing system by taking the breeding results at the base price specified in the agreement (Marliana, 2008). So far, in the core of plasma pattern, the partnership on the chicken field that runs, companies provide means of livestock production in the form of DOC, feed, vaccines/vitamins, technical guidance, and marketing results. On the other hand, the plasma provides cages and labor (Nasir, 2011). The main objective of the partnership is to develop an independent and sustainable development (Self-propelling Growth Scheme) with a solid base, economic structure, as well as economic justice to the people as the main backbone (Salam, et al, 2006).

Small and Medium Enterprises. Sudisman et al (1996), suggested that the development of SMEs have a big role in the development of manufacturing industry. The development of small-scale enterprises can overcome the problem of unemployment by using labor-intensive technology so as to increase employment and opportunities in business. Based on the law no.9 of 1995 concerning small business, it is said that the economic activity of people is set in maximum annual sales by IDR 1 billion and have a net worth, excluding land and building, as well as a business place at most IDR 200 million (Sudisman \& Sari, 1996: 5).

\section{METHODOS OF RESEARCH}

The problems in this study are about the partnership concept application between PT. Charoen Pokphand Indonesia through its subsidiary of PT. Sinar Sarana Sentosa and SMEs (broiler chicken breeders) in improving the business growth in Blitar. This is conditional and can be developed after the research is done. This study aims to analyze problems of partnership application and its supporting factors as well as the inhibitors. By that, it is possible that the theory of broiler chicken partnership is developed further. According to Kriyantono (2006: 69), the descriptive approach in a research is aimed to describe the issues in sequence, in order, and valid in the facts and properties of particular population or object. Researchers already have the concept and conceptual framework. Through the conceptual framework (theoretical basis), the researcher operates the concept that will produce the variables along with the indicators. This research is used to describe the reality without having to explain the relationship between variables. Moleong (2009: 11) said that that the data collected are in the form of words and pictures so that the report will contain direct quotes from the interviews or other data to provide an overview of the report assessment. Besides that, this research is confirmative. It just analyzes the issues discussed once it is confirmed. The data contained in the research are interviews, field notes, company data, or maybe documentation photographs taken from the research observations.

\section{RESULTS AND DISCUSSION}

A deeper understanding of the partnership context in the assisted areas of PT. SSS in Blitar needs to be continuously improved as it can be seen from the results of the above data that there are still some unclear concepts concerning the partnership as a whole. This needs more in-depth socialization. Partnership, in this case, can be described as a form of empowerment. In the context of community empowerment, this statement has two meanings. First, in the empowerment process, there is a strong side to empower the weak. It can be said to be effective because there are companies (core) that are pleased to help or empower small farmers with supporting facilities and infrastructure. The form of compensation earned by the SMEs has a hope to improve the performance of broiler chicken SMEs; this needs to be done due to several problems. This is expected that by the presence of this compensation, it is able to reduce the mortality rate of chicken and chicken disease thus FCR (Feed Conversion Ratio) becomes better or in accordance with the standard. The development of human resources, especially in broiler chicken breeding, is very necessary for the development of broiler chicken which the demand keeps on increasing day per day. 
This potential needs to be considered to further improve the productivity of the existing broiler chicken breeders in Blitar.

Certainly, the increasing production of broiler chicken is a good impact to improve the quality of breeders' life. Therefore, the training activities of broiler chicken breeding are very influential to increase the production of broiler chicken among other breeders around the partner area. Training can encourage the availability/supply of broiler chicken to be always stable in the market. The most common obstacle in optimizing the supply of broiler chicken is the condition where the demand is higher than the rate of production. In this case, counseling is basically an education. The target is that farmers need to experience behavioral changes starting from a simple aspect to a more advanced level. Therefore, the main task of breeding socialization is to help the farmers in making decisions. The involvement of the government and PT.SSS in handling broiler chicken breeding is expected to support the improvement of this breeding business in Blitar because it receives direct counseling. Essentially, as a livestock product that is always needed by the community, broiler chicken breeding in Blitar has big potential as one of the commodities that can be developed by the community. In this case, one who has a role in the development of broiler chicken breeding is the activity of socialization that it is one of the livestock department programs assisted by partner companies.

Supporting and inhibiting factors from the implementation of the partnership program between PT.Sinar Sarana Sentosa with SMEs in Garum, Srengat, and Gandusari of Blitar Regency. The first supporting factor is the condition of partnership company that must be big. Charoen Pokphand has a market share of fodder by $38 \%$, DOC by $37 \%$, and processed chicken meat by $66 \%$ in 2015 . This is because Charoen Pokphand has a large business scale. The advantage with the existence of contract between business partner is the certainty of market and price such as the partnership done by PT Charoen Pokphand through PT.SSS with local chicken breeders. By doing this partnership and by the existence of contract which have been clear and agreed by both parties, this makes many benefits for breeders. Breeders could obtain marketing and price certainty that will be accepted by the company so that when the price of chicken is dropped, breeders can still be calm because there is a certainty of price from the company. On the other hand, PT. SSS also get benefits with this contract, the company will receive a fixed and continued supply so that the production efficiency can be improved. In addition to that, the company will also get benefits when the chicken prices soared. Company does not need to pay high to farmers because of the contracts that have been arranged in advance. If there is a decrease and rise of chicken prices, the process will run in accordance with the partnership contract. The second supporting factor is the availability of DOC and feed that is maintained. Adequate DOC and feed supplies will enhance the development process of broiler chicken breeding and production. Goods that are generated must ensure the effectiveness of company's marketing activities to ensure the continuity operation and to achieve the goal to maximize the value of the company rights. The last supporting factor is that mentoring and counseling are often understood as separate and distinct activities, but in fact, mentoring and counseling have a common purpose and in line to each other. Therefore, the Livestock Department of Blitar and PT. SSS have a cooperation through the extension of workers to provide technical guidance for the community such as capital, science, technology, information on livestock services, veterinary services, technical assistance, avoidance of fees that generate high cost economy, and partnership to increase synergy among business actors.

Inhibiting Factors. The first inhibiting factor is the high mortality of chickens especially broiler chicken. This is one factor that can affect the sustainability of the independent broiler breeding business. The number of broiler chicken that died both the DOC and finisher has caused huge losses for breeders. Losses caused by high mortality affect the decision of the breeder to stop his business. From some sources of this study, it is stated that mortality has triggered the breeders to stop the business. The average breeder has a business scale of 1500 heads. Meanwhile, the average mortality rate is $100-500$ in the harvest. Mortality is a major factor affecting the sustainability of the independent broiler breeding business. It is known that the factors affecting mortality rates are body weight, chicken type, climate, 
hygiene, ambient temperature, equipment sanitation, cages, and diseases. This is a big problem for breeders because broiler chickens aged 5-8 weeks have higher mortality rate than the chickens aged 2-4 weeks. A high mortality rate will cause a big loss for breeders. This is in accordance with the opinion of Bell and Weaver (2002) that broiler chicken maintenance is successful if the overall mortality rate is less than 5 . The mortality rate is affected by age. High mortality rates can affect breeders' income and even cause considerable losses.

The second inhibiting factor is the high level of disease, the disease in broiler chicken always becomes a constraint in the development of this business. In other words, this business cannot be separated from some chicken diseases. The causes of the disease are quite complex, ranging from bacteria, viruses, protozoa, and parasites. Some of the popular chicken diseases in Indonesia include Cronic respiratory disease, coryza, Newcastle disease (ND) or commonly called as tetelo, gumboro, dysentery, Colibacillosis, and Avian influenza which becomes a frightening enemy for breeders lately. In the first option, there also kinds of losses that are ready to pounce. Will a market capacity still exist if chickens continue to be maintained? Because only certain customers who want to receive big chickens. Planning this livestock business certainly and carefully, choosing the chicken strain that best suits the natural surrounding conditions, using high-quality livestock feed, doing the best possible maintenance activity, and not forgetting the favorable market aspect. Apart from the outbreak of disease, broiler chicken in the age of 1 to 7 days is very vulnerable to experience death. The last inhibiting factor is the high level of losses caused by the uncertain timing of the harvest. This becomes one of the big problems in a business. High losses can affect the sustainability of a business. Under normal conditions, the breeders will be easy to sell a ready-cut broiler chicken. While if the supply is higher than demand, breeders will have difficulty in selling their products. Here lies the absence of certainty which can cause breeders to sell broiler chicken at cheap prices. As a result, breeders will experience losses, a lot of chicken prices will fluctuate. Price is one of the factors that influence the sustainability of the independent broiler chicken breeding business. Chicken prices can rise when feed prices also rise. However, farmers are afraid to sell the chicken at high prices because it will affect the volume of sales. If the price is set too high, there will be less profit. In this case, the buyer will decrease, sales volume will decrease, all costs may not be covered so that the business will be shut down. High demand for broiler chickens will only happen on particular days. It usually happened before Idul Fitri holiday. The price will rise up in the second week of Ramadhan month and will reach its peak in 2-3 days before the holiday.

The impact of implementation of the partnership between PT. Sinar Sarana Sentosa with SMEs in Garum, Srengat, and Gandusari of Blitar Regency. One of the people that set up a breeding farm in Sutojayan, Srengat, and Gandusari of Blitar Regency still contributes to the community in the local village. The majority of the workers are farmers and breeders. There are workers who only depend on farming or breeding and there also civil servants, businessmen, and others but only a few. One of the people who become entrepreneurs through the business of broiler chicken breeding is established in Garum, Srengat, and Gandusari. In establishing the breeding farms ideally, they have a private yard. They should not establish a livestock that is close to aresidential area because it will disturb the stabilities and activities of the community in daily life and will also impact on the public health when the breeding activities have started.

Education is one of the main factors in the formation of a person's personality. Education is instrumental in the development of the nation so that it must be supported by adequate infrastructure facilities within its implementation. In addition to formal education, non-formal education also greatly affects breeders in increasing the experience as well as in the decision-making related to the efforts of business development.A large number of livestock is one of the important factors of production. If the business has produced a lot of products, then it will also affect the income of the farmers. Many job opportunities and businesses are open with the existence of this broiler chicken breeding activities both as a chicken breeder, cage labor, chicken traders, sellers of chicken pieces, sellers and processors of chicken manure, processors of chicken food products and other businesses 
both in the upstream and downstream sector of this broiler chicken breeding business activity. The economic aspects include all activities that support the farmer's economy rates such as capital convenience, increased income, management activity, ease of marketing, and increased volume of broiler chicken. With the existence of PT. SSS, the efficiency of losses can be minimized and new job fields in livestock sub-sector could be opened in Blitar. The most important impact of the company in an area is to absorb new employment for local workers. This assumption is intended to provide opportunities in reducing unemployment in Blitar because of the education level that is not maximal. Increasing Local Own Revenue for Blitar Regency. A mastery of technology acquired by plasma breeders can help them to breed the broiler chicken well. However, the company has not been able to empower farmers to be independent. Conversely, companies give an impact of dependency to plasma farmers. This issue is needed to be done on a scale. The utilization of biosecurity by the company is intended to improve production quality.

\section{CONCLUSION}

Based on the results of interviews with broiler chicken breeders, the guidance by core companies still not maximize the agreed programs. It is advisable for core companies to improve the services provided. Breeders of broiler chicken should have more intense communication with PT. SSS and with the Livestock Department of Blitar in order to reduce the level of losses resulting from the lack of understanding of contract system in the partnership pattern. SMEs should be more active in learning the pattern of partnership. The broiler chicken management is already right so that it can continue to minimize the level of loss borne. The quality of service in the context of the partnership is already good enough as a whole but still needs to be improved in order to satisfy the plasma breeders better. Eventhough it is partially benefited from the presence of the partnership, it is not impossible that plasma breeders will cease to associate with a particular core to look for other core companies as having a better quality of service.

The livestock department acts as a legal umbrella and as a facilitator between the SMEs actors and PT. SSS. They should continue to monitor so that breeders can continue to grow and able to be a regional economic support in Blitar. The Livestock Department must monitor the report directly from PT. SSS to make the company becomes more transparent with the farmers, not only on financial problems but also with other things in the partnership. By that, there will be no expectation from the farmers because of there still some unclear things in this partnership context. Overall, the authors conclude that there is still a lot of research that needs to be done. Suggestion for further research concerning the relationship analysis between the subsidiary company and PT. Sinar Sarana Sentosa, as well as other companies, are expected so that a study that could really help both SMEs and companies as its partner can be obtained.

\section{REFERENCES}

1. Abidin, Z. 2002. Meningkatkan Produktivitas Ayam Ras Pedaging. Jakarta: Agromedia.

2. Direktorat Jenderal Peternakan. 2001. Peluang usaha Ternak Ayam Broiler/Ras Usaha Budidaya Peternakan. Jakarta: Bina UKM.

3. Hamidi. 2004. Metode Penelitian Kualitatif: Aplikasi Praktis Pembuatan Proposal dan Laporan Penelitian. Malang: UMM Press.

4. Hartono, R. 2000. Minimisasi Biaya Produksi Usaha Ternak Ayam Broiler dalam Pola Kemitraan. Bulletin Peternakan.

5. Hertanto, A.A. 2009. Kemitraan Usaha Ras Pedaging: Kajian Posisi Tawar Dan Pendapatan. Unpublished Graduate Thesis.

6. Kriyantono, R. 2009. Teknik Riset Praktis Komunikasi. Jakarta: Kencana.

7. Moleong, L. 2009. Metodologi Penelitian Kualitatif: Edisi Revisi. Bandung: PT. Remaja Remaja.

8. Muslimin. 2002. Budidaya Bina Ayam. Yogyakarta: Kanisius. 
9. Rasyaf, M. 2004. Mengapa Peternakan Saya Rugi? (Cetakan Kedelapan). Yogyakarta: Penerbit Kanisius.

10. Rasyaf, M. 2002. Manajemen peternakan ayam broiler. Jakarta: PT. Penebar Swadaya.

11. Rasyaf. M. 1993. Beternak Ayam Pedaging: Edisi Revisi. Jakarta: Penebar Swadaya.

12. Rita, Y. 2009. Analisis Efisiensi Produksi Usaha Peternakan Ayam Ras Pedaging Pola Kemitraan dan Mandiri di Kota Palu Propinsi Sulawesi Tengah. Unpublished Graduate Thesis. Universitas Diponegoro.

13. Salam, T, Muis M, Rumengan AE. 2006. Analisis Finansial Usaha Peternakan Ayam Broiler Pola Kemitraan. Jurnal Agrisistem, Juni 2006, Vol.2, No.1.

14. Saragih, B.2000. Agribisnis Berbasis Peternakan. Bogor: Pustaka Wirausaha Muda.

15. Siahaan, Amiruddin, Rambe dan Mahidin. 2006. Manajemen pengawas pendidikan. Jakarta: Quantum Teaching.

16. Suparta, N. 2001. Perilaku Agribisnis dan Kebutuhan Peternak Ayam Ras Pedaging. Unpublished Dissertation. Bogor: Institut Pertanian Bogor.

17. Syaukani H R; Afan Gaffar; M Ryaas Rasyid. 2004. Otonomi Daerah dalam Negara Kesatuan. Yogyakarta: Pustaka Pelajar.

18. Tobing, V.2005. Beternak Ayam Broiler Bebas Antibiotika: Murah dan Bebas Residu. Jakarta: Penebar Swadaya.

19. Usman, S. 2004. Pembangunan dan Pemberdayaan Masyarakat. Yogyakarta: Pustaka Pelajar. 